\title{
ONLINE MARKETING FOR ACADEMIC LIBRARY: BEST PRACTICE DI PERPUSTAKAAN UNIVERSITAS AIRLANGGA SURABAYA
}

\author{
Ani Sistarina, Agung Budi Kristiawan \\ Perpustakaan Universitas Airlangga \\ E-mail: anisistarina@staf.unair.ac.id
}

\begin{abstract}
ABSTRAK
Kunci keberhasilan sebuah program tentu sangat di dukung oleh bagus dan gencarnya promosi bagi program tersebut. Di era milenial seperti sekarang sosial media adalah sarana yang sangat digemari oleh para pemustaka yang kebanyakan dari generasi milenial. Mereka sudah sangat familiar dengan gawai dan juga terus eksis di dunia maya dan sosial media. Melihat fenomena tersebut sebagai lembaga yang selalu dituntut untuk bergerak maka Perpustakaan Universitas Airlangga juga mengambil bagian dalam penggunaan sosial media sebagai sarana promosi paling efektif saat ini. Penggunaan sosial media sebagai media promosi memiliki peran yang besar bagi keberhasilan program-program yang di tawarkan oleh Perpustakaan Universitas Airlangga kepada pemustakanya seperti halnya program library class yang di buat oleh divisi Pelatihan dan Pengembangan sebagai sarana komunikasi kebutuhan informasi bagi pemustakanya. Library class yang ditawarkan adalah Library 101, Online Research Management, styling and formatting (MS Word), Reference Manager (Mendeley), plagiarism checker (Turnitin). Dimana program ini sangat diminati oleh pemustaka khususnya oleh para mahasiswa strata 2 dan 3 berkat promosi yang sangat masif oleh humas Perpustakaan Universitas Airlangga melalui media sosialnya.
\end{abstract}

Keywords: library class, literasi informasi, promosi, sosial media, online marketing

\section{PENDAHULUAN}

Sebagai salah satu fasilitas yang diberikan oleh universitas, perpustakaan kini mulai berbenah, bukan hanya sebagai tempat untuk membaca, meminjam atau bahkan tempat berkumpul namun telah merubah diri sebagai tempat belajar. Belajar dengan beragam media seperti melalui media sosial, berkelompok dengan memanfaatkan ruang yang diperuntukkan untuk kegiatan tersebut, atau belajar yang diselenggarakan oleh perpustakaan sendiri. Berkaca kembali ke fungsi dasar perpustakaan yakni informasi, budaya, rekreasi bahkan edukasi, dan di bagian akhir inilah perpustakaan mencoba untuk melakukannya.

Informasi saat ini sungguh seperti belantara hutan, di mana setiap orang bisa mendapatkannya namun memerlukan penanganan khusus sehingga yang didapatkan tidak berupa kabar bohong atau hoax melainkan sumber ilmu pengetahuan baru sehingga mampu meningkatkan keahlian para pemustakanya. Disinilah diperlukan literasi informasi dimana menurut (Soelistyo-Basuki, 2013) adalah pemahaman kebutuhan informasi seseorang, dilakukan dengan kemampuan untuk menemukan dan menilai informasi yang relevan serta menggunakannya secara tepat sehingga program ini patut diberikan pada pemustaka perguruan tinggi yang tingkat pendidikan yang telah berbeda dari jenjang sebelumnya. Perpustakaan perguruan tinggi berbeda dengan perpustakaan sekolah ataupun model sumber informasi lainnya. Menurut (Junaeti, 2016) Perpustakaan perguruan tinggi adalah perpustakaan yang melayani para mahasiswa, dosen, dan karyawan. Perpustakaan perguruan tinggi didirikan dengan tujuan untuk mendukung, memperlancar, dan meningkatkan kualitas pelaksanaan program Tri Dharma Perguruan Tinggi melalui pelayanan informasi kepada sivitas akademika yang dilayaninya 15 . Dalam pelayanan kepada masyarakat sivitas akademika, perpustakaan perguruan tinggi akan selalu meningkatkan kualitas layanan, maupun unsur pustakawannya. Untuk memanfaatkan sumber yang dimiliki, Perpustakaan Universitas Airlangga (PUA) memiliki tanggung jawab sehingga menelurkan program Library Class (LC) yang terbagi menjadi beberapa subjek. Untuk mewujudkannya, PUA memutuskan membuat sebuah divisi baru yang khusus menangani kegiatan ini, 
Penelitian dan Pengembangan atau yang dikenal sebagai LATBANG mengemban tugas ini dari hari ke hari. Konsep LC pun digodog sehingga pemustaka nantinya mampu dengan benar memanfaatkan sumber informasi.

Library Class, dibagi menjadi beberapa subjek dan pembagian ini diberikan, karena segmen pemustaka di PUA yang cenderung memiliki kebutuhan yang berbeda. Sebagai sebuah media pembelajaran baru, membutuhkan sentuhan dalam memasarkannya. Pemasaran di era sekarang yang sudah menggunakan cara internet secara masif, sangat diperlukan. Seperti uraian (Mihaela, 2014) "Today it is necessary that organizations to understand why the integrated marketing communication programs have become so important in their activity, especially after 1990". Poster yang tertempel atau media cetak, hanya diperlukan sebagai back up. Internet, sarana media marketing di era saat ini, memiliki beberapa jalur, melalui laman atau website dan media sosial.

Berdasarkan survei yang dilakukan oleh lembaga media sosial dari Canada hootsuite dan dari Inggris We Are Social, Pada Januari 2019, penduduk Indonesia yang menggunakan telepon pintar sebanyak $60 \%$ dan angka ini cukup fantastis dan akan terus meningkat setiap bulannya.

Telepon pintar atau masyarakat lebih dekat mengenalnya dengan nama smartphone telah begitu akrab dengan kehidupan sehari-hari dari memesan makanan, gosip hingga pengetahuan bisa dilakukan hanya dengan satu klik. Pemilik ponsel saat ini, juga memanfaatkan media sosial untuk mengetahui beragam informasi yang didapatkannya.

Media sosial yang banyak dipergunakan saat ini di Indonesia adalah YouTube, Facebook, Instagram, Twitter dan Line, sedangkan untuk aplikasi pesan, mereka menggunakan WhatsApp. Dari beragam media sosial diatas, Perpustakaan Universitas Airlangga (PUA) telah memiliki dan dipergunakan sebagai sarana memperkenalkan ke pemustaka sehingga dapat dengan mudah menjangkau mereka kapan saja.

Library Class (LC), menangkap itu dan untuk kelancaran program ini, media sosial yang dimiliki oleh PUA dipergunakan untuk memasarkan secara gencar sehingga dapat memenuhi target yang diinginkan.

\section{PEMBAHASAN}

Guna memenuhi target yang diinginkan, Devisi Pelatihan dan Pengembangan (Latbang), mengidentifikasi setiap kebutuhan pemustakan melalui survei dan observasi sehingga akhirnya ditentukanlah segmen kelas yang akan diberikan. Latbang mengklasifikasi beberapa library class yang disesuaikan dengan kebutuhan informasi pemustaka yang diantaranya adalah:

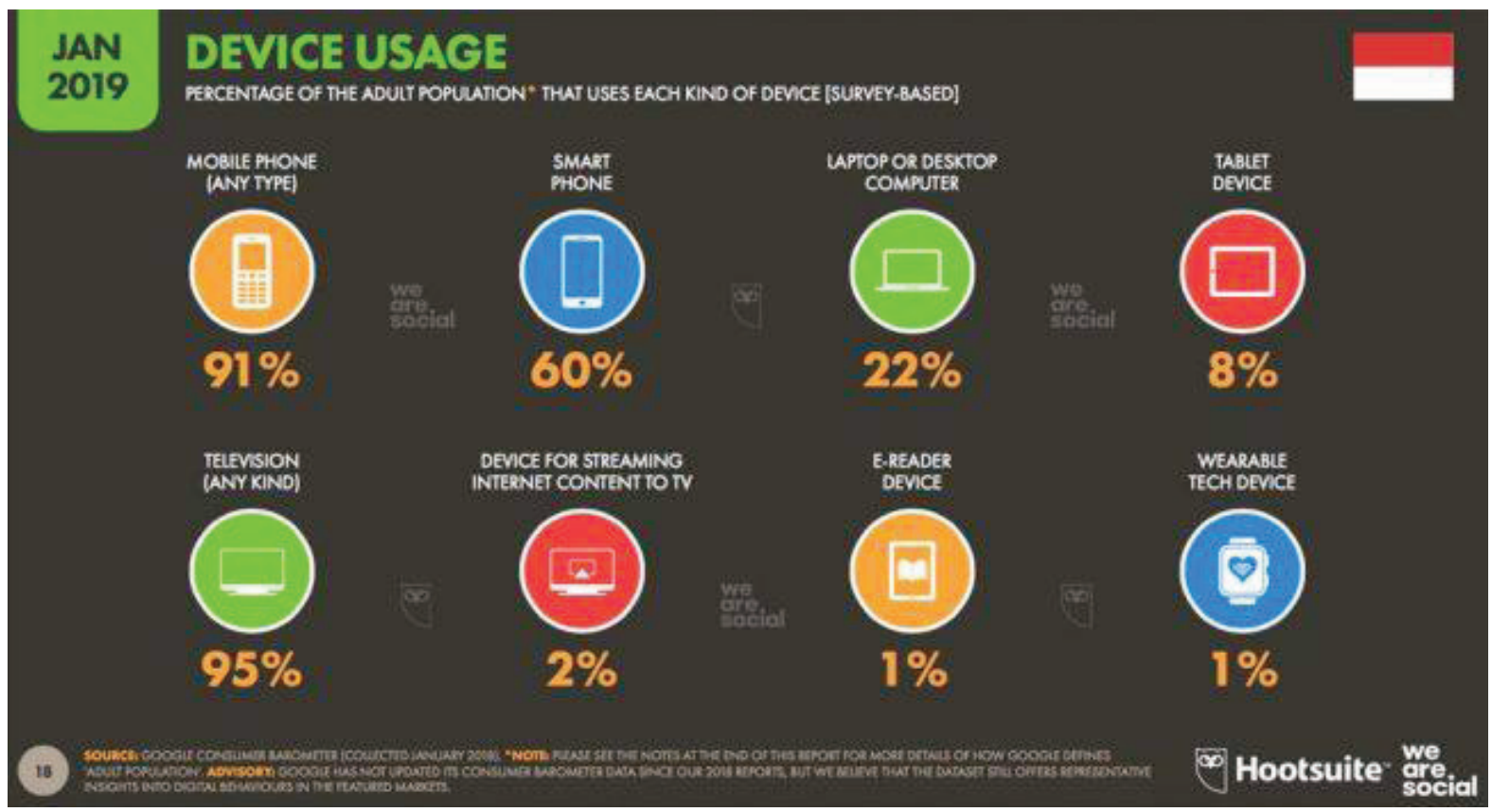

Gambar 1. Survei Penggunaan Gawai di Indonesia terhitung hingga Januari 2019. 


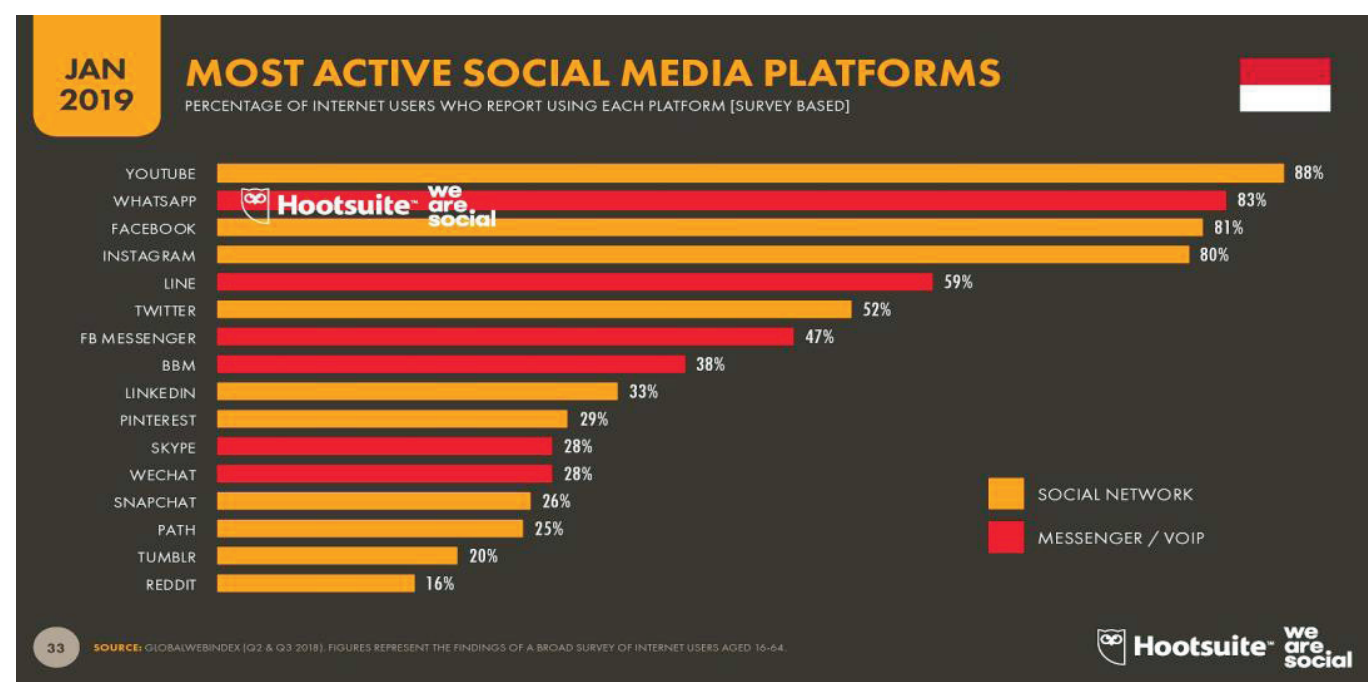

Gambar 2. Pengguna media sosial di Indonesia

\section{Library 101}

Library 101, adalah nama sebuah kelas yang diciptakan sebagai media pembelajaran secara mendasar bagaimana mengakses informasi yang dimiliki untuk mahasiswa yang berada di jenjang strata 1 , diploma 3 dan 4. Pembelajaran mendasar ini diberikan kepada pemustaka khususnya mahasiswa baru yang belum sepenuhnya mengetahui bagaimana pola atau sistem yang terjadi di Perpustakaan Universitas Airlangga. Pembelajaran diarahkan dengan cukup sederhana yakni bagaimana memasuki Perpustakaan Universitas Airlangga, peraturan yang diperbolehkan dan tidak diperbolehkan, bagaimana mengakses informasi melalui katalog dan mendapatkan buku yang diinginkan serta memanfaatkan jurnal yang dilanggan dan juga mengenalkan event-event menarik yang diselenggarakan Perpustakaan Universitas Airlangga.

Universitas Airlangga melalui perpustakaan telah melanggan banyak database journal dan ebook untuk kebutuhan sumber informasi bagi pemustaka untuk kebutuhan studinya. Untuk memaksimalkan penggunaan sumber informasi online tersebut maka Latbang telah membuat kelas khusus yang membahas itu semua. Kelas yang di buat adalah Online Research Management yang biasa dikenal dengan ORM, kelas ini merupakan program lanjutan dari Library 101 yang dikhususkan untuk pemustaka pada jenjang Strata 2 dan 3 atau strata lain yang kebutuhan dasarnya adalah bagaimana mengoptimalkan penggunaan e-resources guna mempermudah dan memperlancar studi mereka. Kelas ORM menyajikan materi untuk mempermudah pemustaka mencari jurnal dan ebook yang sesuai dengan kebutuhan studi mereka, disampaikan juga tips dan trik bagaimana mencari jurnal dengan lebih efektif menggunakan Boolean Operator dan juga google sintax. Dikelas ini pula akan disampaikan strategi submit jurnal internasional dan juga menganalisis trend penelitian dengan menggunakan indexing jurnal. E-resource yang dilanggan oleh Perpustakaan Universitas Airlangga juga dapat diakses dari jaringan di luar kampus oleh sivitas akademika dengan menggunakan remoteXs, tentang bagaimana cara mendaftar dan penggunaannya juga akan dijelaskan dalam kelas ini.

\section{Reference Manager (Mendeley)}

Dalam menulis sebuah karya ilmiah baik artikel, skripsi, tesis, disertasi dan karya-karya ilmiah lain dituntuk untuk menggunakan kaidah penulisan yang baku. Mulai dari tata bahasa hingga cara pengkutipan atau cara mensitasi tulisan orang lain ke dalam tulisan kita. Saat ini telah banyak bertebaran aplikasi yang membantu penulis ataupun peneliti untuk mempermudah mengelola daftar bacaan dan cara mensitasinya, baik yang gratis maupun yang berbayar. Menangkap kebutuhan pemustaka dalam mengelola daftar bacaan maka Latbang membuat kelas reference manager dengan menggunakan aplikasi Mendeley. Dalam kelas ini dijelaskan bagaimana membuat akun Mendeley secara online, mengenalkan fitur-fitur yang ada dan mengoperasikan Mendeley desktop hingga bagaimana mensitasi sebuah tulisan dan juga menyusun daftar pustaka dari tulisan yang disitasi. 


\section{Formating dan Styling (MS Word)}

Mungkin akan banyak yang bertanya kenapa kelas MS Word ditawarkan divisi latbang sebagai bagian dari kelas Literasi informasi di Perpustakaan Universitas Airlangga. Pada kenyataannya belum banyak orang yang tahu dan memahami kegunaan setiap item yang ditawarkan di Microsoft Word, sehingga fungsinya saat ini tidak lebih sebagai alat untuk melakukan pengetikan sebuah tulisan. Padahal dengan mengoptimalkan semua fungsi yang ada akan sangat memudahkan penggunanya seperti misal pembuatan daftar isi secara otomatis, daftar tabel, dan juga pengaturan header dan footer. Atas dasar kenyataan diatas maka divisi Latbang Perpustakaan Universitas Airlangga membuka kelas Formating dan Styling (MS Word) untuk menjawab kebutuhan pemustaka dalam menyusun tulisan yang sesuai dengan kaidah penulisan yang baik dan benar.

\section{Plagiarism Checker (Turnitin)}

Menilik fenomena plagiarisme dalam dunia pendidikan, khususnya saat mengumpulkan tugas seperti makalah, laporan ataupun bentuk-bentuk tugas yang lain, lembaga pendidikan tinggi harus menyikapi hal ini secara serius. Untuk itu perlu diberlakukannya sistem kewajiban untuk mengecek tingkat similarity, program ini bukan hanya membantu dosen dalam mengecek tingkat similarity tulisan mahasiswa, tapi mahasiswa sendiri juga dapat menilai seberapa jauh kemampuan mereka dalam melakukan paraphrasing dari referensi yang mereka baca. Ini tentu akan memotivasi mahasiswa untuk terus belajar bagaimana melakukan paraphrasing yang baik dan benar, supaya aman dari plagiarisme. Dengan kata lain, sistem ini akan mendidik mahasiswa untuk menulis dengan bahasa mereka sendiri. Telah banyak aplikasi-aplikasi yang menawarkan fungsi plagiarism checker ini baik yang gratis maupun berbayar, salah satu aplikasi yang dilanggan oleh Universitas Airlangga adalah Turnitin.

Perlunya sosialisasi pemanfaatan aplikasi ini dimanfaatkan oleh Perpustakaan Universitas Airlangga untuk membuka library class Plagiarism Checker (Turnitin).

\section{Integrasi semua media sosial Facebook, Instagram, LINE dengan layanan WA}

\section{Facebook}

Menurut (Mutia, 2013) keberadaan Facebook banyak membantu perpustakaan sebagai information dan knowledge center dalam menyebarkan informasi secara cepat dan tepat. Facebook sebagai salah satu situs di internet dapat dijadikan media komunikasi massa yang memiliki fungsi sama dengan media massa lainnya yaitu menginformasikan (to inform), mendidik (to educated), menghibur (to entertaint) dan mempengaruhi (to influence) orang lain, dalam hal ini pemustaka perpustakaan. Facebook yang dikelola oleh Bagian Hubungan Masyarakat (Humas) di Perpustakaan Universitas Airlangga ini memberikan ragam isi yang bermanfaat bagi penikmatnya yakni dengan memuat ragam event, situasi dan kondisi (fasilitas dan koleksi) yang dimiliki dan diselenggarakan Perpustakaan Universitas Airlangga. Media sosial yang didirikan oleh Mark Zugenberg yang penggunanya telah mencapai 1 miliar orang ini menjadi sarana yang dimanfaatkan oleh library class dalam memasarkan subjek-subjeknya. Perpustakaan Universitas Airlangga sudah memiliki Facebook sejak 2008 namun saat itu menggunakan akun personal dan sekarang page sehingga lebih mudah menjangkau siapapun dan dapat diketahui ketermanfaatannya. Perpustakaan Universitas Airlangga Page, memiliki 4000'an pengikut yang setiap hari terpantau cukup aktif. Library class ditampilkan dalam folder khusus sehingga engagement setiap pengikut yang memantau dapat diketahui. Selain menampilkan library class yang akan datang, Latbang juga melaporkan semua kegiatan library class melalui foto-foto yang juga ditampilkan di sana sehingga pemustaka yang belum bergabung, menjadi terpacu suatu saat nanti bisa mengikuti. Media sosial, memerlukan penanganan khusus karena peruntukkan atau segmen yang mengikuti juga berbeda dan memiliki keunggulan masing-masing. Facebook memiliki banyak keunggulan diantaranya, mampu memuat banyak foto dan video dan dapat menyiarkan siaran langsung lebih dari satu jam dan disimpan di lini masa. Facebook selain bisa diakses melalui personal komputer juga bisa dilakukan melalui mobile sehingga dapat menjangkau siapa saja. Namun saat ini, facebook lebih menjangkau kalangan senior, atau untuk pelanggan S2 dan S3 atau pelanggan yang telah beranjak dewasa. Guna mengotimalkan kunjungan ke Facebook, Bagian Humas, selaku pengelola, memberikan warna berbeda, yakni menampilkan produk Talkshow ringan dan membahas seputar dunia perpustakaan. Latbang pun pernah mengisi dan mewarnai program \#H5M, demikian nama programnya. Dalam perbincangan singkat tersebut, Latbang bertutur mengenai ragam kegiatan library class dan kegiatan seminar atau bahkan workshop yang dilakukan. 


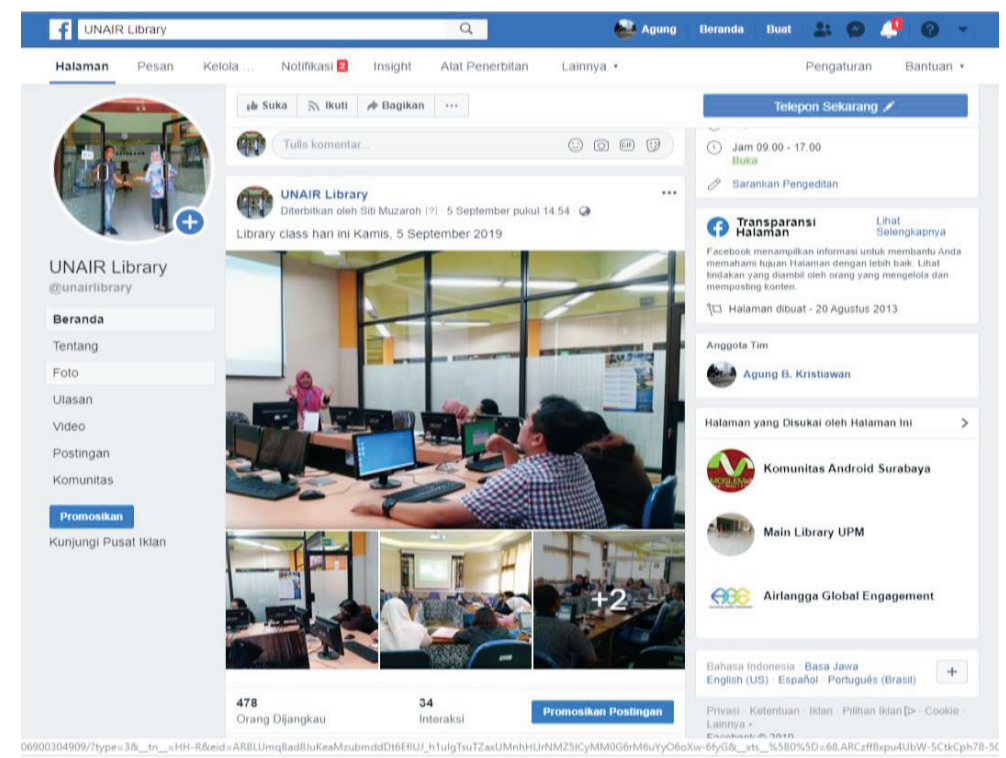

Gambar 3. Potret Library Class yang diwartakan via Facebook

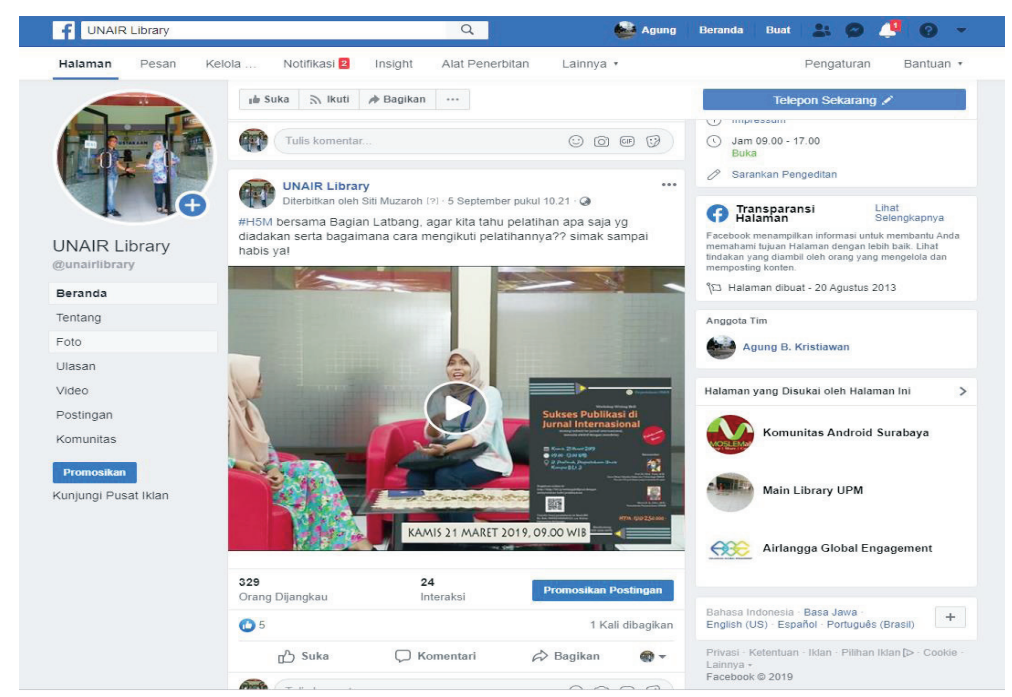

Gambar 4. Promosi Bagian Latbang di Program Perbincangan Facebook H5M

\section{Instagram (IG)}

Sebagai media sosial berbagi foto, library class menampilkan beberapa foto terbaik di bagian feed saat acara telah selesai. Library class yang paling banyak peminat adalah saat liburan semester tiba. Library class dibuat dan diperuntukkan bagi mahasiswa yang butuh asupan untuk menyelesaikan tugas akhir atau karya penelitiannya. Program library class berlangsung 3 hari dengan sajian subjek yang berbeda. IG diberikan slot untuk menampilkan materi promosi ini hanya melalui fitur stories yang sangat digandrungi oleh instagramer. Melalui fitur ini, interaksi pun terjadi sehingga mereka yang tertarik dapat langsung memberikan pesan melewati layanan direct messenger-nya. Dari ragam feed dan stories yang dilakukan oleh bagian Humas Perpustakaan Universitas Airlangga, komunikasi tentang library class sangat tinggi dan ini terlihat juga dengan hadirnya banyak peserta di Program Holiday library class Juli lalu. IG Perpustakaan Universitas Airlangga sendiri saat ini telah memiliki 2900'an pengikut yang rata-rata diakses stories kurang lebih 700 orang per harinya. 


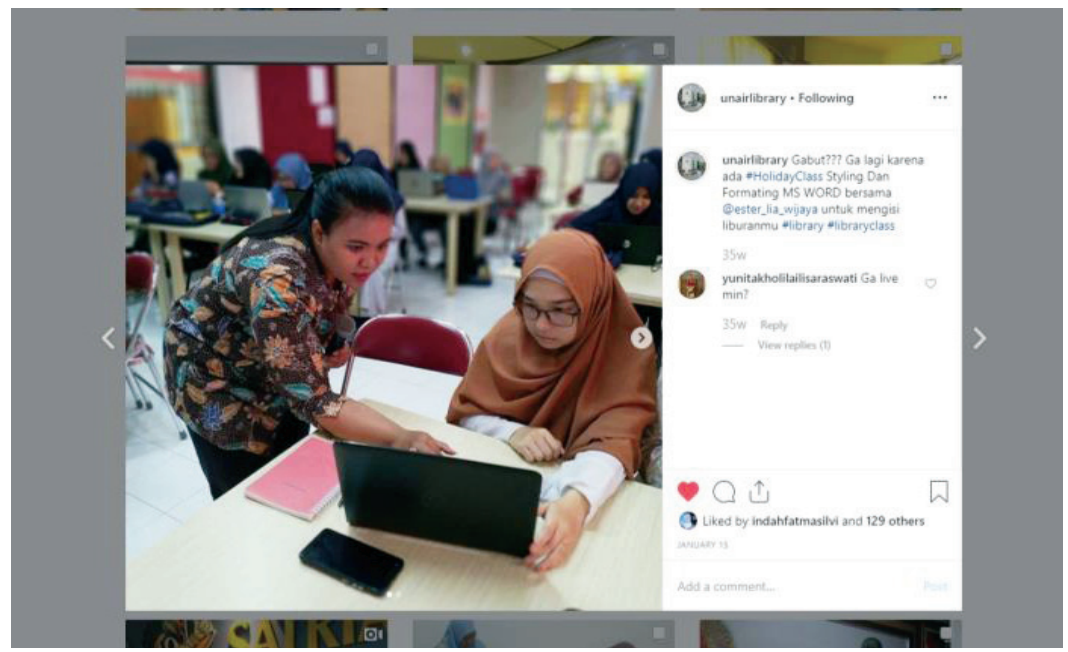

Gambar 5. Program Library Class on Holiday Session

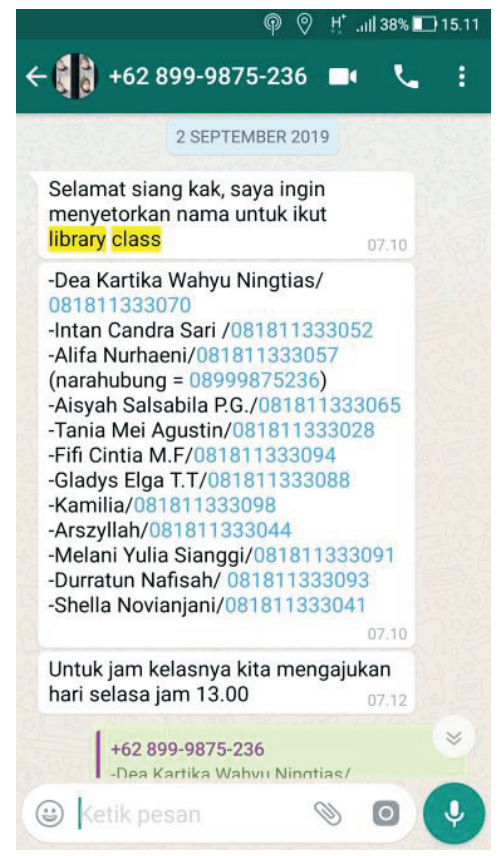

Gambar 6. Library Request on WhatsApp

\section{LINE}

LayananLINE@ merupakan layanan yang dipakai oleh PUA untuk melakukan aktivitas promosinya khususnya menggunakan fitur broadcast message (BM) setiap kali bila memiliki event khususnya library class. Media sosial dari Jepang ini, dipakai oleh lebih banyak pemustaka karena identik dengan kaum muda. Kurang lebih 6000'an orang mengikuti dan dijangkau oleh PUA.
Selain menggunakan fitur BM, lini masa LINE juga dimanfaatkan oleh library class untuk mempromosikan kegiatannya.

\section{WhatsApp}

Ketiga media sosial diatas, serasa kurang bila WhatsApp tidak mengikuti. Ditengah pulsa telepon yang mahal, WA memberikan alternatif terbaik dalam 
berkomunikasi khususnya di era digital saat ini. WA juga menggantikan fungsi pesan singkat konvensional atau SMS yang dapat sampai ke tangan penggunanya dengan mudah. Semua hal terkait dengan library class selalu mencantumkan nomor WA PUA sehingga pemustaka dapat dengan mudah berinteraksi dengan Latbang. Bahkan dari aplikasi ini, library class kini membuka layanan permintaan atau dikenal dengan Library Class by request di mana semua pemustaka dapat memesan sendiri kelas dari subjek yang diinginkan dan disesuaikan dengan jadwal mereka yang luang. Program yang diluncurkan Latbang ini, mendapat reaksi cepat dari pemustaka yang selama ini tidak bisa mengikuti library class reguler yang dicanangkan Tim Latbang sendiri. Mereka pun berbondong-bondong mendaftar melalui layanan WA.

\section{PENUTUP}

Sebuah program dalam perpustakaan dan sebagus apapun program itu dibuat tanpa adanya promosi sama seperti berbuat hal yang sia-sia. Kunci keberhasilan sebuah program tentu sangat di dukung oleh bagus dan gencarnya promosi bagi program tersebut. Di era milenial seperti sekarang sosial media adalah sarana yang sangat digemari oleh para pemustaka yang kebanyakan dari generasi milenial. Mereka sudah sangat familiar dengan gawai dan juga terus eksis di dunia maya dan sosial media. Melihat fenomena tersebut sebagai lembaga yang selalu dituntut untuk bergerak maka Perpustakaan Universitas Airlangga juga mengambil bagian dalam penggunaan sosial media sebagai sarana promosi paling efektif saat ini. Penggunaan sosial media sebagai media promosi memiliki peran yang besar bagi keberhasilan program-program yang ditawarkan oleh Perpustakaan Universitas Airlangga kepada pemustakanya seperti halnya program library class yang dibuat oleh divisi Pelatihan dan Pengembangan sebagai sarana komunikasi kebutuhan informasi bagi pemustakanya.

\section{DAFTAR PUSTAKA}

Junaeti. (2016). Peranan Perpustakaan dalam Meningkatkan Peran Perpustakaan Perguruan Tinggi. Libraria, 4(1).

Mihaela, O.O.E. (2014). The Influence of The Integrated Marketing Communication on The Consumer Buying Behaviour. In Procedia Economics and Finance.

Mutia, F. (2013). Pemanfaatan jejaring sosial (Facebook) Perpustakaan Perguruan Tinggi sebagai Pemenuhan Kebutuhan Informasi Mahasiswa.

Soelistyo-Basuki. (2013). Literasi Informasi dan Literasi Digital. Retrieved from https://sulistyobasuki. wordpress.com/2013/03/25/literasi-informasi-danliterasi-digital/. 